\title{
Legislation to boost US technology takes protectionist turn in House
}

Washington. Legislation to improve US competitiveness by helping industry to exploit new technology is being attacked by companies it is designed to help because an amended version would exclude participation by other countries.

The National Competitiveness Bill (HR 820 ), which includes measures ranging from the creation of local research centres for manufacturing technology to federal grants for some types of industrial research and development, was passed last month by the US House of Representatives; a similar version (S.4) awaits approval in the Senate. But two amendments approved during debate in the House give it a decidedly protectionist flavour.

The first, offered by Representative Thomas Manton (Democrat, New York) and Cardiss Collins (Democrat, Illinois), would exclude non-US companies from participation. The change was accepted reluctantly by the bill's sponsors, led by Representative Tim Valentine (Democrat, North Carolina), as a compromise to placate Representative John Dingell (Democrat, Michigan) and to prevent the bill from being referred back to the Energy and Commerce Committee, which Dingell chairs. The second amendment, offered by Mac Collins (Republican, Georgia), would effectively exclude any US company with foreign nationals on its board.

The bill, a central component of the Clinton administration's programme to strengthen US technology, would authorize the spending of $\$ 1.5$ billion over two years on a series of local centres, research grant schemes and training initiatives to promote manufacturing technology. The National Science Foundation (NSF) and the National Institute of Standards and Technology (NIST) would administer the bulk of the programme.

But the main lobbying group for industry, the National Association of Manufacturers (NAM), has withdrawn its support for the House version. It thinks that the MantonCollins amendment would exclude thoroughly US multinational companies such as Kodak and IBM, as well as non-US companies with strong US research operations, such as the electronics group Philips. This week in Brussels, the European Commission is considering its response to what one European diplomat in Washington described as "a clear case of a non-tariff barrier to trade".

Opponents of the Manton-Collins amendment expect to prevail in the Senate, with help from the White House. But the outcome of a conference later this summer to reconcile differences in the two versions will depend in large part on Dingell's attitude. "We're certainly hoping to get it killed", says Bill Morin of NAM about the US-only provisions. "But it's a question of how far Dingell digs in his heels."

The Senate version is similar to the unamended House version, but also contains provisions for the development of a
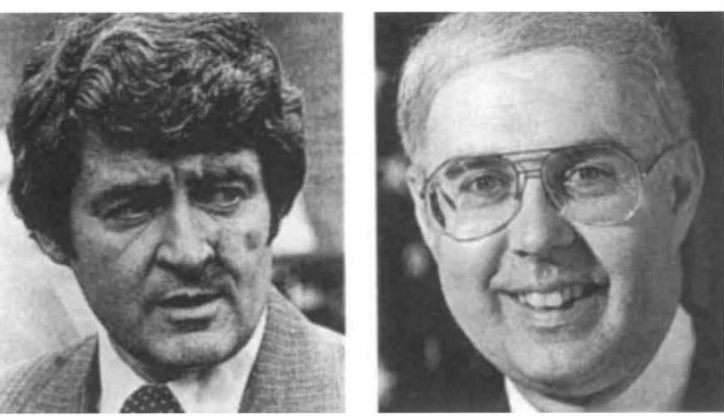

Manton (at left) amends, Walker objects.

high-speed telecommunications network. The House is addressing that issue in a separate bill (see Nature 363, 104; 1993).

The Manton-Collins amendment requires that companies participating in schemes authorized in the bill must agree to manufacture any resulting products in the United States and to "procure parts and materials for such products from competitive US suppliers". A spokesman for Kodak says that these stipulations would exclude it and other US-owned multinational companies.

The amendment also requires the home

\section{Germany wants to modify gene laws}

Munich. The German government has drafted changes to its restrictive gene laws so as to speed up and simplify procedures for obtaining permission to do low-risk experiments. But the draft, which faces a long and rocky road, offers researchers no relief from the procedures required for experiments defined as having no risk (see Nature $\mathbf{3 5 9}$, 93; 1992).

The current laws make it extremely difficult to conduct any experiment involving recombinant DNA. The proposed changes would halve the two-month waiting period at the state level for low-risk (safety level 2) experiments, and protocols would no longer need to be approved again by the federal Commission for Biological Safety. The requirement for public hearings on produc- countries of foreign-owned companies wishing to participate to satisfy a list of criteria including the existence of a programme "equivalent to this Act" and a process for setting non-discriminatory industrial standards. The latter is seen by foreign manufacturers as a catch-all clause to exclude them.

Representative Robert Walker (Republican, Pennsylvania), the senior Republican on the Science, Space and Technology Committee, criticizes the amendment as "purely protectionist". Walker argues that the requirement for "equivalent" research support schemes in other countries is far stricter than previous laws, which require only "comparable" schemes, and could never be met. Supporters of the amendment concede that its intention is to keep out non-US companies, but say that the result will be no different than what happens abroad to US-owned companies.

The acceptance by the House of the Manton-Collins language, which is unquestionably tougher than previous provisions of this type, reflects two things. One is the long shadow cast by Dingell's committee over a bill championed by the science committee, chaired by Representative George Brown (Democrat, California). The second is the prevailing mood in the House of protectionism and even isolationism. After the amendment by Mac Collins was passed 288:127, Brown said that the current mood may foil efforts to rejoin UNESCO and could also damage other forms of international science collaboration.

Colin Macilwain would also be removed.

But the draft law does not eliminate any of the extensive documentation required for experiments defined as having no risk. A directive from the European Communities that Germany has chosen to read literally says that even no-risk experiments must be monitored, and Germany has further complicated the process with an additional layer of bureaucracy.

The draft must first be approved by the Bundesrat (upper house), where the socialist majority is expected to weaken it. The next step, approval by the cabinet, is also subject to review by the Bundesrat. The process is expected to take at least until the end of the year.

Alison Abbott tion facilities using low-risk procedures 